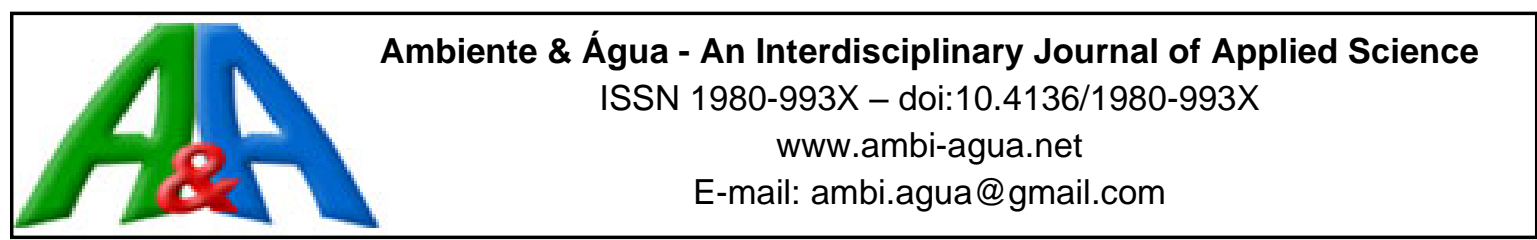

\title{
Microplastics in Nile tilapia (Oreochromis niloticus) from Lake Amatitlán
}

\author{
ARTICLES doi:10.4136/ambi-agua.2754
}

Received: 20 May 2021; Accepted: 10 Aug. 2021

\author{
Bessie Evelyn Oliva-Hernández ${ }^{*}$; Francis Mariel Santos-Ruiz ${ }^{(D)}$ \\ Manuel Alejandro Muñoz-Wug ${ }^{\mathbb{D}}$; Juan Francisco Pérez-Sabino \\ Facultad de Ciencias Químicas y Farmacia. Escuela de Química. Universidad de San Carlos de Guatemala, \\ Ciudad Universitaria, Edificio T12, zona 12, 01012, Ciudad de Guatemala, Guatemala. \\ E-mail: francissantos94@gmail.com,mwmanuel@yahoo.com,fpsabino@usac.edu.gt \\ *Corresponding author. E-mail: bessieoliva@yahoo.com
}

\begin{abstract}
Microplastics are plastic particles smaller than $5 \mathrm{~mm}$ found in the environment, which can cause health problems for aquatic organisms and humans, being classified as emerging pollutants. In Guatemala, Lake Amatitlán is one of the most polluted lakes as it receives discharges of wastewater, treated and untreated, as well as other waste from Guatemala City and other major urban populations. In a recent study, microplastics were found in sediments in Lake Amatitlán, so it was necessary to determine whether the lake's fish are affected by these pollutants, which can be harmful to their health. This research aimed to determine the microplastics in fish from Lake Amatitlán, for which 65 specimens of Nile tilapia (Oreochromis niloticus) were collected in October and December 2020, and January 2021. The collected fish were dissected in the laboratory, where the number and type of microplastics were analyzed in the digestive tract, after their separation by digestion and filtration. Lines or fibers were the most common type of microplastics, found in 63 specimens ( $96.9 \%$ of the analyzed specimens), ranging from 0 to 27 lines/fibers per individual. The frequency of other types of microplastics found were 0-3 fragments/individual, 0-2 films/individual, and 0-4 foams/individual, while microspheres were not found in any specimen. The presence of microplastics in tilapia from Lake Amatitlán is an indicator of contamination in the lake by pollutants that could affect the trophic network and represents a risk for the fish consumers, requiring the attention of environmental and health authorities.
\end{abstract}

Keywords: emerging pollutants, Guatemala, pollution.

\section{Microplásticos em tilápia do Nilo (Oreochromis niloticus) do Lago Amatitlán}

\section{RESUMO}

Microplásticos são partículas plásticas menores que $5 \mathrm{~mm}$ encontradas no meio ambiente, que podem causar problemas à saúde dos organismos aquáticos e humanos, sendo classificados como poluentes emergentes. Na Guatemala, o Lago Amatitlán é um dos lagos mais poluídos, pois recebe descargas de águas residuais, tratadas e não tratadas, bem como outros resíduos da Cidade da Guatemala e de outras populações urbanas. Em um estudo recente, foram 
encontrados microplásticos em sedimentos do Lago Amatitlán. Então era necessário saber se os peixes do lago estão ingerindo microplásticos, que podem ser prejudiciais. Assím, o objetivo desta pesquisa foi determinar os microplásticos em peixes do Lago Amatitlán, para o qual foram coletados 65 exemplares de tilápia do Nilo (Oreochromis niloticus) nos meses de outubro e dezembro de 2020 e janeiro de 2021. Os peixes foram dissecados no laboratório, onde o número e tipo de microplásticos foram analisados no trato digestivo, após sua separação por digestão e filtração. Linhas ou fibras foram o tipo de microplástico mais comum, sendo encontradas em 63 espécimes (96,9\%), variando de 0 a 27 linhas / fibras por indivíduo. A frequência de outros tipos de microplásticos encontrados foi de 0-3 fragmentos / indivíduo, 0-2 filmes / indivíduo e 0-4 espumas / indivíduo, enquanto microesferas não foram encontradas em nenhum espécime. A presença de microplásticos na tilápia do Lago Amatitlán é um indicador de contaminação do lago por poluentes que podem afetar a rede trófica e representa um risco para os consumidores de peixe, exigindo atenção das autoridades ambientais e sanitárias.

Palavras-chave: contaminação, contaminantes emergentes, Guatemala.

\section{INTRODUCTION}

Lake Amatitlán is located $25 \mathrm{~km}$ south of Guatemala City. It has an approximate area of $15 \mathrm{~km}^{2}$, and is surrounded by the municipalities of Villa Nueva, Villa Canales, San Miguel Petapa and Amatitlán. It is one of the most polluted water bodies in Guatemala, as it receives the waste water from Guatemala City through the Villalobos River, its major tributary. High levels of nutrients, pesticides and heavy metals have been found in the lake, which have caused the lake's eutrophication and high risk of diseases for human beings (Basterrechea, 1997; van Tuylen, 2020; Knedel et al., 1999). Since the 1990s, different decisions have been made to reduce lake pollution, which have decreased the input of traditional pollutants (López, 2013); However, emerging pollutants, including microplastics, had not been considered, of which several have polluted the water for decades, and only recently have begun to get any attention (Geissen et al., 2015).

Microplastics are all plastic particles smaller than $5 \mathrm{~mm}$ found in the environment (Bellasi et al., 2020), either by direct discharge or by the degradation of larger plastic materials (Barboza et al., 2020). The intensive and ubiquitous use of plastic in the last century has given rise to extensive contamination of water bodies worldwide (Espinosa Ruiz et al., 2016), generating microplastics from different sources, either as primary microplastics that are small plastics produced as raw material or end- product or as secondary microplastics that are produced from the disintegration of plastics of a larger size (Thiele et al., 2021). Microplastics are an emerging pollutant of growing concern, not only because of their direct negative effects, but because they are assumed to increase the exposure of aquatic organisms to associated chemicals. These pollutants are ingested by aquatic organisms, in which they can cause health problems and even death, as well as bioaccumulation and biomagnification of microplastics in the food chain (Cole et al., 2011; Xu et al., 2020). The ingestion of microplastics affects the physiology and behavior of aquatic animals and introduces this pollutant to the trophic chains (Espinosa Ruiz et al., 2016). Microplastics can also adsorb pollutants such as heavy metals and organic pollutants, facilitating their entry into the food chain and increasing the risk for aquatic organisms and humans (Bollaín Pastor and Agulló, 2019; Wilkinson et al., 2017). Due to their size and color similar to those of some natural prey, microplastics are ingested by aquatic organisms such as fish, invertebrates or even aquatic birds, and can cause negative effects to them (Yuan et al., 2019).

The Nile Tilapia (O. niloticus) was introduced into the lakes of Guatemala, including Lake Amatitlán, between 1950-1960, in order to promote the economic growth of the basin 
inhabitants. Different studies have shown that Lake Amatitlán is highly polluted with heavy metals; recently arsenic, mercury and cadmium were found in the muscle of fish in the lake (González, 2010; Cano Alfaro, 2018) as well as quantifiable levels of cyanotoxins, such as microcystins (Romero-Oliva et al., 2014); however, no studies had been carried out to identify and quantify microplastics. Most of the studies on contamination by microplastics have been carried out in the oceans, meanwhile the studies in continental waters are still insufficient (Bollaín Pastor and Agulló, 2019; Yuan et al., 2019). Lakes are the main sinks for microplastics in freshwater ecosystems, as these pollutants can accumulate and remain in sediments for long periods of time. Likewise, lakes can also become sources of microplastics for downstream watersheds (Yuan et al., 2019).

In other countries, microplastics and phthalates have been found in freshwater and saltwater fish (Baini et al., 2017), while recently microplastics were found in sediments from Lake Amatitlán (Romero Oliva, 2019), in water from Lake Petén Itzá (Mejía Saenz, 2019) and water and fish from Lake Atitlán (López, 2013; Sagastume, 2020; Santos Ruíz, 2020), which shows that there is contamination by microplastics in water bodies in Guatemala. In this way, the authors considered it important to determine if the tilapias of Lake Amatitlán are affected by microplastics present in the environment, which could threaten its health and represent a risk for consumers.

The importance of studying these emerging pollutants is based upon the fact that it is unknown, on the one hand, in which environmental components they are found, and on the other, the effects that they may be causing in the aquatic ecosystem and the risk to the health of the human population in contact with water or consuming fish from contaminated water bodies (Geissen et al., 2015). Due to this lack of knowledge, the allowed levels for these pollutants have not yet been included in the water quality standards or in the regulation of wastewater or food. Thus, it is necessary to investigate their presence and identity in order to make proposals for the better disposal of plastic waste.

To address part of these knowledge gaps, this study identified microplastics in $O$. niloticus from Lake Amatitlán and captured information regarding the size, sex and condition index of the fish consuming microplastics, through a descriptive study, with a non-probabilistic sampling design. The type and quantity of microplastics extracted from the gastrointestinal tract of fish collected by local fishermen during three samplings (October 2020, December 2020 and January 2021) were analyzed in order to prove whether the fish of Lake Amatitlán are ingesting microplastics from the aquatic environment at levels that could represent a risk for biota and human health.

\section{MATERIALS AND METHODS}

\subsection{Fish collection}

Fish were collected with the aid of local fishermen, who catch them in various locations of Lake Amatitlán, using a fishing net. The fish were collected at the lake between $05 \mathrm{~h} 00$ and $10 \mathrm{~h} 00$, choosing specimens not smaller than $15 \mathrm{~cm}$ in length for analysis in the laboratory. During the three samplings, 65 individuals of the species Oreochromis niloticus (Nile tilapia) were collected. The fish were transferred to the laboratory where they were stored at freezing temperature for further processing. In the present study, three fish samplings were carried out in the months of October and December 2020 and in January 2021, in Lake Amatitlán,

\subsection{Fish measurement}

Fish length was measured from mouth to tail, with a precision of $1 \mathrm{~mm}$, using a graduated ruler and the specimens were weighed in an electronic semi-analytical balance with a precision of 0.1 grams, according to the methodology of Cifuentes et al. (2012). For all the collected fish, the condition index was determined. 


\subsection{Extraction and purification of microplastics from the fish gastrointestinal tract}

The entire gastrointestinal tract of the 65 collected specimens was dissected and transferred to a $250 \mathrm{ml}$ glass beaker. To digest the organic matter, $25 \mathrm{~mL}$ of a $1.0 \mathrm{M} \mathrm{NaOH}$ solution prepared in the laboratory (Merck, 99-100\% purity) were added to the beaker and heated at $50^{\circ} \mathrm{C}$ in an electric oven for $15 \mathrm{~min}$. The samples were mixed by means of a glass stirring rod to aid alkaline digestion. Each sample was diluted with $125 \mathrm{ml}$ with ultrapure water and vacuum filtered through a $47 \mathrm{~mm}$ diameter Whatman brand fiberglass filter $45 \mu \mathrm{m}$ pore size (Roch et al., 2020).

\subsection{Microplastics classification}

The filters with the recovered microplastics were examined with a dissection microscope (Kyowa Optical, Model SD-2PL) counting the number of each type of microplastics (lines/fibers, fragments, films, microspheres and foams) present in the gastrointestinal tract of the analyzed specimens (Roch et al., 2020).

\subsection{Analysis of results}

The results of the measurements, weights, number and type of microplastic were classified and tabulated, describing what was found in each specimen. The condition index was calculated for each individual according to the Equation 1.

$$
K=100\left(W / L^{3}\right)
$$

Where $\mathrm{W}$ is the wet body weight, in grams and L the length in $\mathrm{cm}$ (Cifuentes et al., 2012). The microplastics determined were classified by type of microplastic in body length intervals of the specimens calculated using the Sturges equation, resulting in seven intervals of $1.3 \mathrm{~cm}$ in length. Because the two groups of larger fish had four $(22.1-23.4 \mathrm{~cm})$ and two individuals $(23.4-24.7 \mathrm{~cm})$, they joined a group of fish with length equal to or greater than $22.1 \mathrm{~cm}$.

The median and interquartile range (IQR) were calculated for each group, since the resulting dispersion was too large to use average and standard deviation, a non-parametric oneway analysis of variance (Kruskal Wallis) was performed. ( $\mathrm{P}<0.05)$, using STATA16 software. Four analyzes were run according to the type of microplastic: lines, fragments, films and foams. In the case of the films, there were no results. The most relevant analysis is that of the fibers: it showed that there is a difference according to the length.

\section{RESULTS AND DISCUSSION}

Table 1 shows the results of the determination of sex, weight, length, condition index and different types of microplastics for the 65 fish collected. Of the 65 specimens collected, 51 were female and 14 male. The lengths of the specimens were between 15.6 and $24.2 \mathrm{~cm}$, with an average of $19.31 \mathrm{~cm}$ and the body weights were between 67.12 and $287.09 \mathrm{~g}$, with an average of $147.0 \mathrm{~g}$ per specimen. The average for the condition index $(\mathrm{K})$ was $1.97 \mathrm{~g} \mathrm{~cm}^{-3}$ ranging from 1.57 to $2.56 \mathrm{~g} \mathrm{~cm}^{-3}$. Microplastics were found in 63 of the 65 specimens analyzed with an average of 9.71 microplastics per individual. The lines/fibers (Figures 1 and 2) were the most common type of microplastics, as there were from 2 to 27 lines or fibers per specimen. One to five fragments were found in 28 specimens, one or two films were found in 12 specimens, and one to four foams were found in 18 specimens. No microspheres were found in any specimen. The results demonstrate that tilapia is ingesting microplastics from the aquatic environment of Lake Amatitlán independently of the weight and length of the specimen. Only two females (44 and 57) did not present any microplastic. The condition index also shows a wide dispersion, unrelated to sex or presence of microplastics. 
Table 1. Determination of weight, length, condition index and microplastics in specimens of Oreochromis niloticus collected in Lake Amatitlán.

\begin{tabular}{|c|c|c|c|c|c|c|c|c|c|}
\hline $\begin{array}{l}\text { Fish } \\
\text { Code }\end{array}$ & Sex & $\begin{array}{l}\text { Weight } \\
\text { (g) }\end{array}$ & $\begin{array}{l}\text { Length } \\
(\mathrm{cm})\end{array}$ & $\begin{array}{l}\text { Condition } \\
\text { Index K } \\
\left(\mathrm{g} \mathrm{cm}^{-3}\right)\end{array}$ & $\begin{array}{l}\text { Lines/ } \\
\text { Fibers }\end{array}$ & Fragments & Films & Foams & Total \\
\hline 1 & Female & 121.51 & 19.5 & 1.64 & 11 & 1 & 0 & 0 & 12 \\
\hline 2 & Female & 139.98 & 20.0 & 1.75 & 18 & 1 & 1 & 0 & 20 \\
\hline 3 & Female & 89.98 & 16.3 & 2.08 & 9 & 1 & 1 & 0 & 11 \\
\hline 4 & Female & 173.69 & 20.6 & 1.99 & 23 & 0 & 0 & 0 & 23 \\
\hline 5 & Male & 125.27 & 18.7 & 1.92 & 11 & 1 & 0 & 0 & 12 \\
\hline 6 & Female & 91.16 & 17.3 & 1.76 & 18 & 0 & 0 & 0 & 18 \\
\hline 7 & Female & 73.33 & 15.6 & 1.93 & 3 & 0 & 0 & 0 & 3 \\
\hline 8 & Male & 119.18 & 18.5 & 1.88 & 6 & 1 & 0 & 0 & 7 \\
\hline 9 & Female & 143.20 & 19.3 & 1.99 & 8 & 1 & 0 & 0 & 9 \\
\hline 10 & Female & 104.94 & 17.0 & 2.14 & 12 & 0 & 0 & 0 & 12 \\
\hline 11 & Male & 111.09 & 17.8 & 1.97 & 7 & 0 & 0 & 0 & 7 \\
\hline 12 & Female & 150.14 & 19.2 & 2.12 & 22 & 2 & 1 & 0 & 25 \\
\hline 13 & Female & 167.82 & 21.0 & 1.81 & 22 & 1 & 2 & 0 & 25 \\
\hline 14 & Female & 172.74 & 20.4 & 2.03 & 16 & 1 & 0 & 0 & 17 \\
\hline 15 & Female & 217.07 & 23.3 & 1.72 & 5 & 0 & 0 & 0 & 5 \\
\hline 17 & Female & 215.25 & 21.7 & 2.11 & 9 & 2 & 0 & 0 & 11 \\
\hline 18 & Female & 186.71 & 21.0 & 2.02 & 5 & 3 & 0 & 1 & 9 \\
\hline 19 & Female & 210.58 & 21.1 & 2.24 & 27 & 1 & 0 & 0 & 28 \\
\hline 20 & Female & 178.06 & 21.6 & 1.77 & 8 & 0 & 0 & 0 & 8 \\
\hline 22 & Female & 212.55 & 22.0 & 2.00 & 4 & 0 & 0 & 0 & 4 \\
\hline 23 & Female & 180.56 & 21.5 & 1.82 & 8 & 0 & 0 & 0 & 8 \\
\hline 24 & Female & 228.94 & 21.8 & 2.21 & 7 & 0 & 0 & 0 & 7 \\
\hline 25 & Female & 273.87 & 23.0 & 2.25 & 14 & 0 & 0 & 0 & 14 \\
\hline 26 & Female & 181.33 & 22.0 & 1.70 & 10 & 0 & 0 & 0 & 10 \\
\hline 27 & Female & 198.36 & 21.0 & 2.14 & 10 & 0 & 0 & 0 & 10 \\
\hline 28 & Female & 205.08 & 22.5 & 1.80 & 20 & 0 & 0 & 0 & 20 \\
\hline 29 & Female & 197.38 & 21.5 & 1.99 & 9 & 0 & 1 & 0 & 10 \\
\hline 30 & Male & 168.06 & 20.5 & 1.95 & 7 & 0 & 0 & 0 & 7 \\
\hline 31 & Female & 170.46 & 20.7 & 1.92 & 18 & 0 & 0 & 0 & 18 \\
\hline 32 & Female & 284.80 & 24.0 & 2.06 & 9 & 0 & 0 & 0 & 9 \\
\hline 33 & Female & 195.18 & 21.5 & 1.96 & 15 & 0 & 0 & 0 & 15 \\
\hline 34 & Female & 67.12 & 17.8 & 1.19 & 4 & 1 & 0 & 1 & 6 \\
\hline 35 & Female & 234.50 & 22.9 & 1.95 & 10 & 1 & 0 & 2 & 13 \\
\hline 36 & Male & 160.04 & 20.5 & 1.86 & 8 & 2 & 0 & 0 & 10 \\
\hline 38 & Female & 173.01 & 20.2 & 2.10 & 4 & 0 & 0 & 1 & 5 \\
\hline 39 & Female & 181.84 & 20.5 & 2.11 & 2 & 0 & 0 & 0 & 2 \\
\hline 40 & Female & 186.36 & 20.5 & 2.16 & 4 & 0 & 0 & 0 & 4 \\
\hline 41 & Male & 123.83 & 16.5 & 2.76 & 4 & 0 & 1 & 3 & 8 \\
\hline 42 & Male & 287.09 & 24.2 & 2.03 & 12 & 1 & 0 & 0 & 13 \\
\hline 43 & Female & 132.26 & 18.5 & 2.09 & 4 & 0 & 0 & 1 & 5 \\
\hline 44 & Female & 154.58 & 19.9 & 1.96 & 0 & 0 & 0 & 0 & 0 \\
\hline 46 & Male & 211.56 & 22.0 & 1.99 & 3 & 2 & 0 & 0 & 5 \\
\hline 47 & Female & 203.99 & 21.6 & 2.02 & 7 & 0 & 0 & 0 & 7 \\
\hline 48 & Female & 97.00 & 17.5 & 1.81 & 4 & 1 & 1 & 1 & 7 \\
\hline 49 & Female & 112.61 & 17.8 & 2.00 & 4 & 0 & 0 & 0 & 4 \\
\hline 50 & Female & 89.59 & 16.5 & 1.99 & 3 & 1 & 0 & 1 & 5 \\
\hline 51 & Female & 116.69 & 18.0 & 2.00 & 6 & 0 & 0 & 1 & 7 \\
\hline 52 & Female & 118.45 & 18.3 & 1.93 & 11 & 1 & 0 & 0 & 12 \\
\hline 53 & Male & 99.21 & 17.0 & 2.02 & 7 & 0 & 0 & 3 & 10 \\
\hline 54 & Female & 110.50 & 17.7 & 1.99 & 16 & 1 & 0 & 0 & 17 \\
\hline 55 & Female & 102.25 & 17.9 & 1.78 & 14 & 3 & 0 & 1 & 18 \\
\hline 56 & Male & 121.99 & 17.5 & 2.28 & 3 & 0 & 0 & 0 & 3 \\
\hline
\end{tabular}

Continue...

Rev. Ambient. Água vol. 16 n. 5, e2754 - Taubaté 2021 


\begin{tabular}{|c|c|c|c|c|c|c|c|c|c|}
\hline \multicolumn{10}{|c|}{ Continued... } \\
\hline 57 & Female & 95.92 & 17.0 & 1.95 & 0 & 0 & 0 & 0 & 0 \\
\hline 58 & Male & 91.26 & 16.7 & 1.96 & 5 & 1 & 0 & 1 & 7 \\
\hline 59 & Female & 99.15 & 16.5 & 2.21 & 3 & 0 & 0 & 0 & 3 \\
\hline 60 & Male & 76.90 & 16.5 & 1.71 & 5 & 1 & 0 & 4 & 10 \\
\hline 61 & Female & 83.81 & 16.1 & 2.01 & 3 & 5 & 0 & 1 & 9 \\
\hline 62 & Female & 93.20 & 17.4 & 1.77 & 2 & 0 & 0 & 1 & 3 \\
\hline 63 & Female & 98.30 & 17.0 & 2.00 & 6 & 1 & 0 & 1 & 8 \\
\hline 64 & Male & 105.86 & 17.8 & 1.88 & 6 & 0 & 0 & 0 & 6 \\
\hline 65 & Female & 94.28 & 17.1 & 1.89 & 5 & 1 & 1 & 0 & 7 \\
\hline 66 & Female & 106.18 & 17.4 & 2.02 & 5 & 2 & 1 & 2 & 10 \\
\hline 67 & Male & 101.43 & 16.0 & 2.48 & 3 & 0 & 0 & 0 & 3 \\
\hline 68 & Female & 88.33 & 17.8 & 1.57 & 1 & 3 & 0 & 0 & 4 \\
\hline 69 & Female & 92.90 & 17.0 & 1.89 & 4 & 0 & 1 & 1 & 6 \\
\hline 70 & Average & 147.70 & 19.32 & 1.97 & 8.45 & 0.68 & 0.17 & 0.42 & 9.71 \\
\hline
\end{tabular}

Source: Proyecto B12-2020.
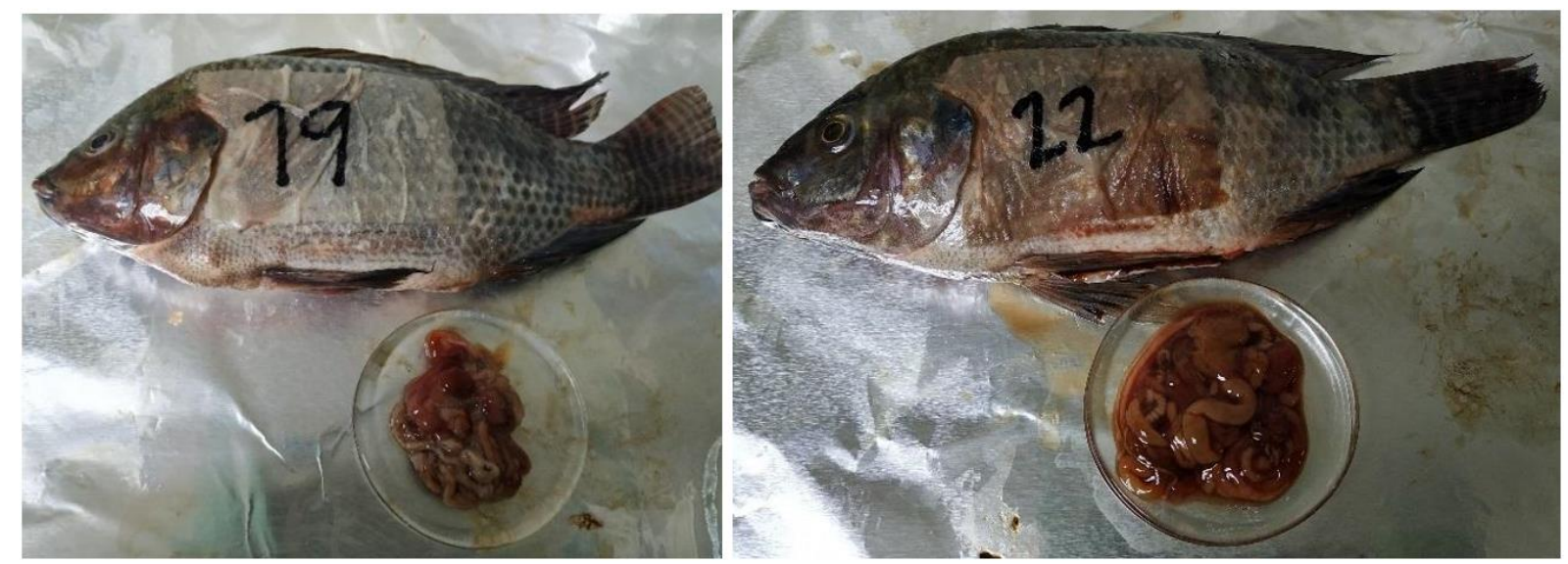

Figure 1. Dissection of the gastrointestinal tract of two tilapia specimens (19 and 22) for extraction of microplastics by alkaline digestion.

Table 2 shows the results of the different types of microplastics found in the gastrointestinal tracts of specimens of $O$. niloticus from Lake Amatitlán, grouped by ranges of body length. Lines/fibers, fragments, films and foams were found, but microspheres were not found in any specimen. Figure 1 shows two of the specimens caught in Lake Amatitlán with the gastrointestinal tract extracted. Groups 3 and 6 presented the highest medians (9.5 and 11, respectively). In the Kruskal Wallis test (not shown), Groups 3 and 6 were significantly different from the rest of the groups. In the case of Group 6, the longest fish, the high median could indicate bioaccumulation of microplastics related to age. According to the results, lines and fibers are the type of microplastics that are most abundantly ingested by tilapia in Lake Amatitlán. The fragments of Groups 1 and 3 presented medians of 1, while for the other four groups the median was 0 . The median of the films for all groups was 0 , while for the foams, only Group 1 presented a median of 1 and the other groups had a median of 0 . Group 1 of smaller fish presented the highest average condition index median (2.01), as well as the lowest median of lines/fibers (3). However, no really relevant differences between condition indexes are found between groups, indicating equivalent nutrition between them. Regarding fish sex, $79.7 \%$ of the captured fish were female and $20.3 \%$ were male, both sexes showing wide dispersion in terms of the number of microplastics present and the condition index, so they cannot be related in this study sample. 
Table 2. Median and interquartile range (in brackets) of condition index and each type of microplastics found in specimens of Oreochromis niloticus from Lake Amatitlán classified by fish body length.

\begin{tabular}{cccccccc}
\hline Group & Length Range $(\mathrm{cm})$ & $\mathrm{n}$ & $\begin{array}{c}\text { Condition index } \\
\left(\mathrm{g} \mathrm{cm}^{-3}\right)\end{array}$ & Lines/fibers & Fragments & Films & Foams \\
\hline 1 & $15.6-16.9$ & 9 & $2.01(0.25)$ & $3(2)$ & $1(1)$ & $0(0)$ & $1(1)$ \\
2 & $16.9-18.2$ & 19 & $1.95(0.22)$ & $5(3)$ & $0(1)$ & $0(0)$ & $0(1)$ \\
3 & $18.2-19.5$ & 6 & $1.96(0.17)$ & $9.5(5)$ & $1(0)$ & $0(0)$ & $0(0)$ \\
4 & $19.5-20.8$ & 11 & $1.96(0.24)$ & $8(7)$ & $0(1)$ & $0(0)$ & $0(0)$ \\
5 & $20.8-22.1$ & 14 & $2.00(0.29)$ & $8.5(3)$ & $0(1)$ & $0(0)$ & $0(0)$ \\
6 & $\geq 22.1$ & 6 & $1.99(0.26)$ & $11(5)$ & $0(1)$ & $0(0)$ & $0(0)$ \\
\hline
\end{tabular}

Source: Proyecto B12-2020.
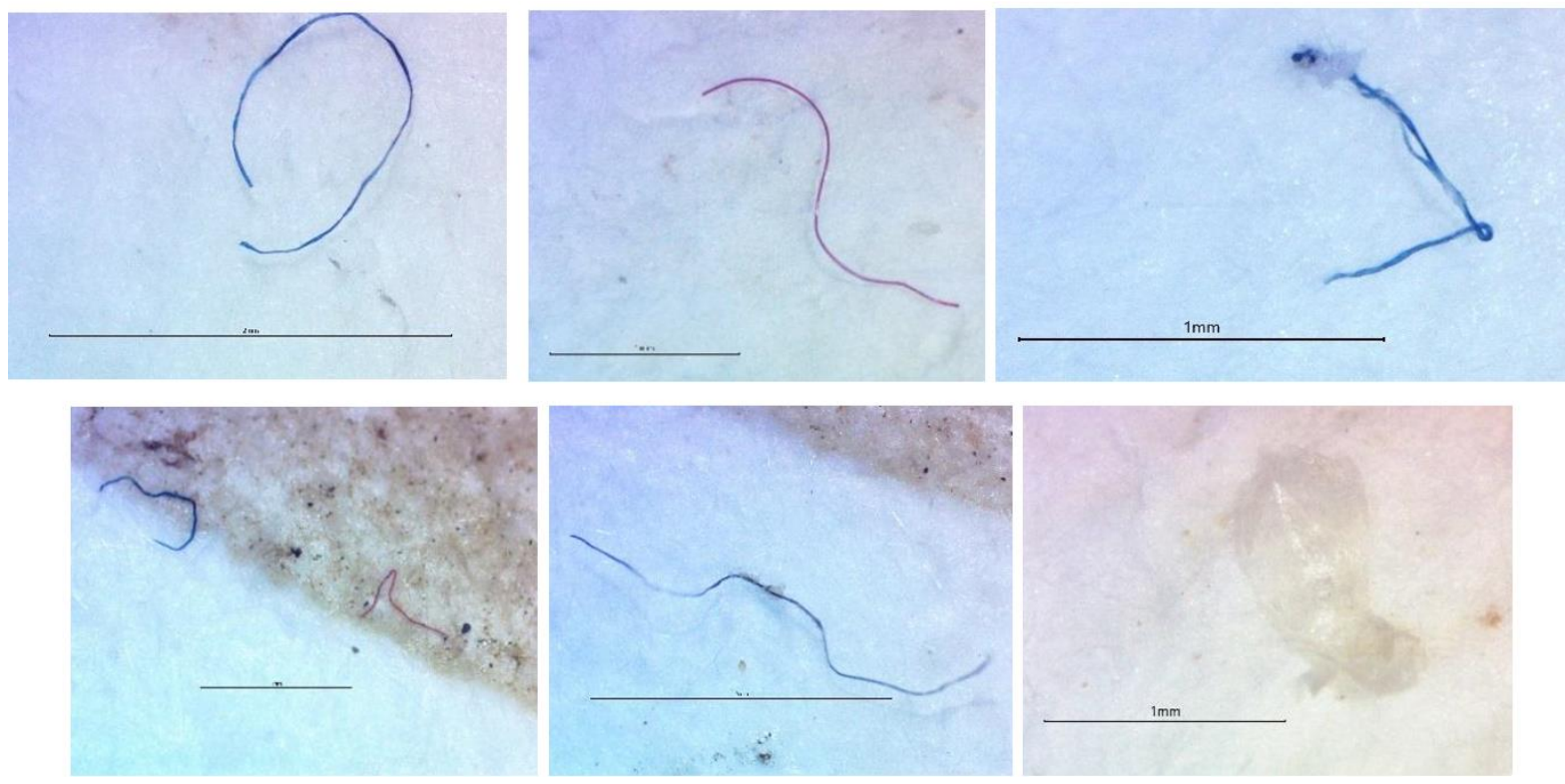

Figure 2. Microscope image of microplastics present in the digestive tract of the fish in Figure 1. Images $\mathrm{a}, \mathrm{b}$ and $\mathrm{c}$ correspond to lines/fibers of individual 19 ; $\mathrm{d}$ and $\mathrm{e}$ to lines/fibers and $\mathrm{f}$ to a fragment of individual 22 (the scale line corresponds to $1 \mathrm{~mm}$ in each image).

The risk of the presence of microplastics in tilapia from Lake Amatitlán is that these pollutants can cause neurotoxicity and oxidative damage to fish (Barboza et al., 2020). Thus, microplastics can reach humans through their consumption. Since tilapia is one of the main products of fishing at the lake and is sold for residents and tourists in the basin. In a recent study, microplastics were found in a sediment core of Lake Amatitlán, with lines being the most abundant microplastics $(n=221)$, followed by fragments and films $(n=37)$ (Romero-Oliva, 2019), which agrees with the frequency with which microplastics were found in fish in the present study. No reports of microplastics in water from Lake Amatitlán were found, but the major source of microplastics in the lake and the ingestion by fish could be caused by pollution coming from the Villalobos River that carries treated and untreated wastewater from southern Guatemala City. Since most of the fish analyzed have ingested microplastics, this pollutant represents a risk to the health and growth of the fish, which can cause a decrease in the productivity of the fishing in the lake. Likewise, microplastics can also adsorb other pollutants from the environment, such as pesticides or polynuclear aromatic hydrocarbons, or contain 
heavy metals, facilitating their transport and entry into organisms and increasing their toxicity (Bollaín Pastor and Agulló, 2019; Vedolin et al., 2018) by being distributed in different organs of fish.

The prevalence of microplastics in tilapia found in this study (96.9\%) is higher than that reported for fish in other studies, including 88\% in Amazon River fish, 70\% in commercial marine fish, or between 39 and $49 \%$ for fish of Mediterranean coastal lagoon at the north of Spain (Rodríguez-Sierra et al., 2020), which may be an indicator of high contamination by microplastics in Lake Amatitlán. Thus, the results show that the fish in Lake Amatitlán may be threatened by contamination by microplastics, if actions are not taken for its control by the environmental authorities of the basin.

\section{CONCLUSIONS}

It was found that tilapias of Lake Amatitlán ingest microplastics from the aquatic ecosystem, with lines / fibers being the most common type of microplastics found in the gastrointestinal tract of the fish analyzed. The presence of microplastics in most of the fish is a good indicator that Lake Amatitlán presents a problem of contamination by these pollutants that can represent a risk for fish health, altering the trophic network and reaching humans. Future studies should address the composition of the microplastics present in fish and in the water of Lake Amatitlán to evaluate possible toxicological effects on the aquatic biota. The results should also be considered by the basin environmental authorities in order to take action to control de contamination by plastics and microplastics.

\section{ACKNOWLEDGMENTS}

This research "Determinación de microplásticos y tierras raras en agua y peces del lago de Amatitlán", was co-financed by Fondo de Investigación de la Dirección General de Investigación, de la Universidad de San Carlos de Guatemala, Digi/Usac2020, partida presupuestaria 2020-11300060-12-00-000-001-000-022-001-22-0000-0000 Investigación Básica No. de proyecto B12-2020". The authors are grateful to the "Autoridad para el Manejo Sustentable de la Cuenca y del Lago de Amatitlán (AMSA)", for the support of aquatic transport to the research team and equipment to the different sampling points in Lake Amatitlán. The authors also want to thank Dr. Jorge Luis de León Arana for his statistical advice.

\section{REFERENCES}

BAINI, M.; MARRELINI, T.; CINCINELLI, A.; CAMPANI, T.; MINUTOLI, R.; PANTI, C. et al. First detection of six phthalate esters (PAEs) as plastic tracers in superficial neustonic/planktonic samples and cetacean blubber. Analytical Methods, v. 9, n. 9, p. 1512-1520, 2017. https://doi.org/10.1039/C6AY02674E

BARBOZA, L. G; LOPES, C.; OLIVEIRA, P.; BESSA, F.; OTERO, V.; HENRIQUES, B. et al. Microplastics in wild fish from North East Atlantic Ocean and its potential for causing neurotoxic effects, lipid oxidative damage, and human health risks associated with ingestion exposure. Science of the Total Environment, n. 717, p. 1-14, 2020. https://doi.org/10.1016/j.scitotenv.2019.134625

BASTERRECHEA, M. EI Lago de Amatitlán: Década de estudios limnológicos 1985-1995. Guatemala, Guatemala City. Guatemala: Academia de Ciencias Médicas, Físicas y Naturales, 1997. 
BELlASI, A.; BINDA, G.; POZZI, A.; GALAFASSI, S.; VOLTA, P.; BETTINETTI, R. Microplastic contamination in Freshwater environments: A review, focusing on interactions with sediments and benthic organisms. Environments, v. 7, n. 4, v, p. 1-28, 2020. https://doi.org/10.3390/environments 7040030

BOLLAÍN PASTOR, C.; AGULLÓ, D. V. Presencia de microplásticos en aguas y su potencial impacto en la salud pública. Revista Española de Salud Pública, v. 93, p. 1-10, 2019.

CANO ALFARO, M. F. Diagnóstico de los cuerpos de agua del lago de Amatitlán. Guatemala. Guatemala City: Autoridad para el Manejo Sustentable de la Cuenca del Lago de Amatitlán, 2018. 62 p.

COLE, M.; LINDEQUE, P.; HALSBAND, C.; GALlOWAY, T. Microplastics as contaminants in the marine environment: a review. Marine Pollution Bulletin, v. 62, n. 12, p. 2588 - 2597, 2011. https://doi.org/10.1016/j.marpolbul.2011.09.025

CIFUENTES, R.; GONZALEZ, J.; MONTOYA, M.; JARA, A.; ORTIZ, N.; PIEDRA, P.; HABIT, E. Relación longitud-peso y factor de condición de los peces nativos del río San Pedro (cuenca del río Valdivia, Chile). Gayana Especial, v. 75, n. 2, p. 101-110, 2012. http://dx.doi.org/10.4067/S0717-65382012000100009

ESPINOSA RUIZ, C. et al. Microplastics in Aquatic Environments and Their Toxicological Implications for Fish. In: SOLONESKI, S.; LARRAMENDY, M. L. (ed.). Toxicology. Rijeka: inTech, 2016.

GEISSEN, V.; MOL, H.; KLUMPP, E.; UMLAUF, G.; NADAL, M.; VAN DER PLOEG, M. Emerging pollutants in the environment: a challenge for water resource management. International Soil and Water Research, n. 3, p. 57-65, 2015. https://doi.org/10.1016/j.iswcr.2015.03.002

GONZÁLEZ, P. Análisis de la contaminación por Plomo y Mercurio en el músculo de las Tilapias Oreochromis niloticus provenientes del Lago de Amatitlán. 2010. 44f. Trabajo de Graduación (Licenciado en Acuicultura) - Universidad de San Carlos de Guatemala, Guatemala, 2010.

KNEDEL, W.; CHIQUIN, J.C.; PÉREZ, J.; ROSALES, S. Estudio de los niveles de residuos de plaguicidas en la cuencas de Amatitlán y del Motagua. (Informe Final. FODECYT 08-97). Guatemala: Consejo Nacional de Ciencia y Tecnología, Universidad del Valle de Guatemala, 1999. 114 p.

LÓPEZ, R. Tratamiento de aguas industriales residuales vertidas en el lago de Amatitlán y su cuenca. 2013. 111f. Trabajo de Graduación (Facultad de Ingeniería) - Universidad de San Carlos de Guatemala, Guatemala, 2013.

MEJÍA SAENZ, A. Contaminación por microplástico en un lago endorreico de tierras bajas: El caso de Petén Itzá. 2019. Thesis (Ciencias Químicas) - Universidad de San Carlos de Guatemala, Guatemala, 2019.

ROCH, S.; FRIEDRICH, C.; BRINKER, A. Uptake routes of microplastics in fishes: practical and theoretical approaches to test existing theories. Scientific Report, v. 10, 1-11, 2020. https://doi.org/10.1038/s41598-020-60630-1 
RODRÍGUEZ-SIERRA, C.M.; ANTÓN-PARDO, M.; QUINTANA, X.D.; ARMENGOL, X. Ingesta de microplásticos por el pez exótico Gambusia holbrooki en dos lagunas costeras mediterráneas. Ecosistemas, v. 29, n. 3, p. 2097, 2020.

ROMERO-OLIVA, C. S.; CONTARDO-JARA, V.; BLOCK, T.; PFLUGMACHER, S. Accumulation of microcystin congeners in different aquatic plant sand crops - A case study from lake Amatitlán, Guatemala. Ecotoxicology and Environmental Safety, v. 102, 121-128, 2014. https://doi.org/10.1016/j.ecoenv.2014.01.031

ROMERO-OLIVA, C. Paleoecotoxicología, una herramienta para la reconstrucción del pasado reciente en el Lago de Amatitlán, Guatemala. Guatemala City: Dirección General de Investigación-Universidad de San Carlos de Guatemala, 2019. 87 p.

SAGASTUME, L. Determinación de microplásticos en contenido gastrointestinal del Bluegill (Lepomis macrochirus) (Rafinesque, 1819) en el lago Atitlán. Guatemala: Universidad de San Carlos de Guatemala, 2020.

SANTOS RUÍZ, F. Microplásticos en sedimentos superficiales en el lago de Atitllán, Sololá, Guatemala. Guatemala: Amsclae-Universidad de San Carlos de Guatemala, 2020.

THIELE, C. J.; HUDSON, M. D.; RUSSELL, A.; SALUVEER, M.; SIDAOUI-HADDAD. Microplastics in fish and fishmeal: an emerging environmental challenge? Nature, v. 20, n. 2045, p. 1-12, 2021. https://doi.org/10.1038/s41598-021-81499-8

VAN TUYLEN, S. Estado de los cuerpos de agua de la Cuenca del Lago de Amatitlán 2020. Guatemala: Autoridad Para el Manejo Sustentable de la Cuenca y del Lago de Amatitlán-AMSA, 2020. 60 p.

VEDOLIN, M. C.; TEOPHILO, C. Y. S.; TURRA, A.; FIGUEIRA, R. C. L. Spatial variability in the concentrations of metals in beached microplastics. Marine Pollution Bulletin, v. 129, n. 2, p. 487-493, 2018. https://doi.org/10.1016/j.marpolbul.2017.10.019

WILKINSON, J.; HOODA, P.S.; BARKER, J.; BARTON, S.; SWINDEN, J. Occurrence, fate and transformation of emerging contaminants in water: An overarching review of the $\begin{array}{llllll}\text { field. Environmental Pollution, n. 231, p. 954-970, } 2017 . & \end{array}$ https://doi.org/10.1016/j.envpol.2017.08.032

XU, S.; MA, J.; JI, R.; PAN, K.; MIAO, A. Microplastics in aquatic environments: occurrence, accumulation and biological effects. Science of the Total Environment, n. 703, p. 134699, 2020. https://doi.org/10.1016/j.scitotenv.2019.134699

YUAN, W.; LIU, X.; WANG, W.; DI, M.; WANG, J. Microplastic abundance, distribution and composition in water, sediments, and wild fish form Poyang Lake, China. Ecotoxicology $\begin{array}{llllll}\text { and Environmental Safety, n. 170, p. } 2019 . & \text { 180-187, }\end{array}$ https://doi.org/10.1016/j.ecoenv.2018.11.126 